\title{
Pengaruh Kebijakan Penurunan Ambang Batas Pembebasan Bea Masuk Nilai Impor Barang Kiriman (De Minimis) terhadap Volume Impor Barang Kiriman Indonesia (PMK No. 199/PMK.10/2019)
}

\author{
Najla Fauziani Deyanputri ${ }^{a, 1, *}$ \\ ${ }^{1}$ Universitas Indonesia, Depok, Indonesia \\ 1 najla.fauziani@ui.ac.id, \\ * corresponding author
}

\section{ARTICLE INFO}

Article history

Received 2020-10-08

Revised 2020-11-24

Accepted 2020-12-31

Keywords

import duties, fiscal policy, deminimical threshold, imports

\begin{abstract}
The increase in the value of Indonesia's imports from 2017-2019 continues to increase. The increase in import value is in line with the increasing volume of imports of consigned goods which tends to increase. The government has issued a policy to reduce the threshold for exemption from import duty on shipments of goods to FOB USD3.00 with the hope of reducing the volume of imported goods and creating justice for domestic producers. This study aims to determine how the effect of the threshold for exemption from import duty on consigned goods affects the import volume of Indonesian consignments. From the results of the study it is concluded that the decrease in the threshold for exemption from import duty on the value of imported goods of shipments suppresses the import volume of Indonesian consignments, although there are factors outside the policy that also affect the import volume of Indonesian consignments.
\end{abstract}

\section{PENDAHULUAN}

Kegiatan impor merupakan salah satu implikasi yang tidak dapat dihindari dari adanya kegiatan perdagangan internasional. Masing-masing negara memiliki keterbatasan sumber daya sehingga perdagangan antar negara merupakan salah satu kegiatan yang dibutuhkan demi memenuhi kebutuhan nasional. Keterbatasan industri lokal dalam memenuhi permintaan masyarakat mengharuskan adanya pemenuhan atas permintaan tersebut dengan melakukan impor. Impor merupakan kegiatan membeli barang dari penjual yang berasal dari luar negeri. Berdasarkan Pasal 1 angka 13 Undang-Undang Nomor 17 Tahun 2006 tentang Perubahan atas Undang-Undang Nomor 10 Tahun 1995 tentang Kepabeanan, definisi impor adalah kegiatan memasukkan barang dari luar daerah pabean ke dalam daerah pabean.

Kegiatan impor tidak hanya sekedar membeli barang jadi dari produsen luar negeri, namun dapat juga mengimpor barang setengah jadi untuk diolah karena keterbatasan teknologi industri lokal dalam tahap proses produksi. Keterbatasan teknologi yang dialami oleh industri lokal dapat menyebabkan biaya produksi menjadi lebih tinggi. Hal ini dapat menyebabkan harga jual barang menjadi lebih mahal, jika dibandingkan dengan melakukan impor barang jadi serupa dari negara yang biaya produksinya lebih rendah. Ditambah dengan pemberian fasilitas dalam rangka impor, sehingga tidak begitu menambah biaya yang akan mempengaruhi harga jual. Konsumen cenderung akan memilih barang dengan harga yang lebih murah. Sebab harga menjadi salah satu faktor yang mempengaruhi seseorang dalam membeli barang (Frederick, 1995). Manusia cenderung memilih barang yang memiliki harga lebih murah.

Dalam melakukan impor akan timbul serangkaian prosedur yang wajib dilaksanakan agar barang tersebut dapat diterima oleh konsumen. Setiap negara memiliki kebijakan masing-masing dalam hal mengatur dan mengawasi alur perdagangan internasional. Pemerintah Indonesia menggunakan instrumen kebijakan fiskal dengan mengenakan bea masuk dan/atau cukai serta pajak dalam rangka impor (PDRI) yang terdiri dari PPh Pasal 22, PPN dan PPnBM. Pada umumnya, negara-negara lain juga mengandalkan instumen fiskal sebagai wujud proteksi selain dengan memanfaatkan kebijakan non tarif seperti pembatasan kuota impor dan dumping.

Bea masuk adalah biaya yang dikenakan untuk masuknya barang dari luar daerah pabean ke dalam daerah pabean (Purwito, 2015). Kebijakan pemberlakuan bea masuk merupakan salah satu 
kebijakan umum yang digunakan oleh banyak negara sebagai bentuk proteksi terhadap industri dalam negeri dan sebagai sumber penerimaan pendapatan negara. Dasar hukum pengenaan bea masuk diatur dalam Undang-Undang Nomor 17 tahun 2006 tentang Kepabeanan. Pada pasal 2 angka 1 disebutkan bahwa barang yang dimasukkan ke dalam daerah pabean diperlakukan sebagai barang impor dan tertutang bea masuk. Secara spesifik pada Pasal 13 ayat (1) huruf b disebutkan bahwa bea masuk dapat dikenakan berdasarkan tarif yang berbeda untuk beberapa jenis barang salah satunya barang kiriman melalui pos.

Nilai impor Indonesia dalam neraca perdagangan dari tahun 2015 sampai dengan tahun 2018 cenderung mengalami kenaikan. Hal tersebut ditunjukkan dalam grafik Nilai Impor Indonesia dari tahun 2015 sampai tahun 2019 berikut ini.

Grafik 1. Nilai Impor Indonesia Tahun 2015-2019

(dalam US\$ Juta)

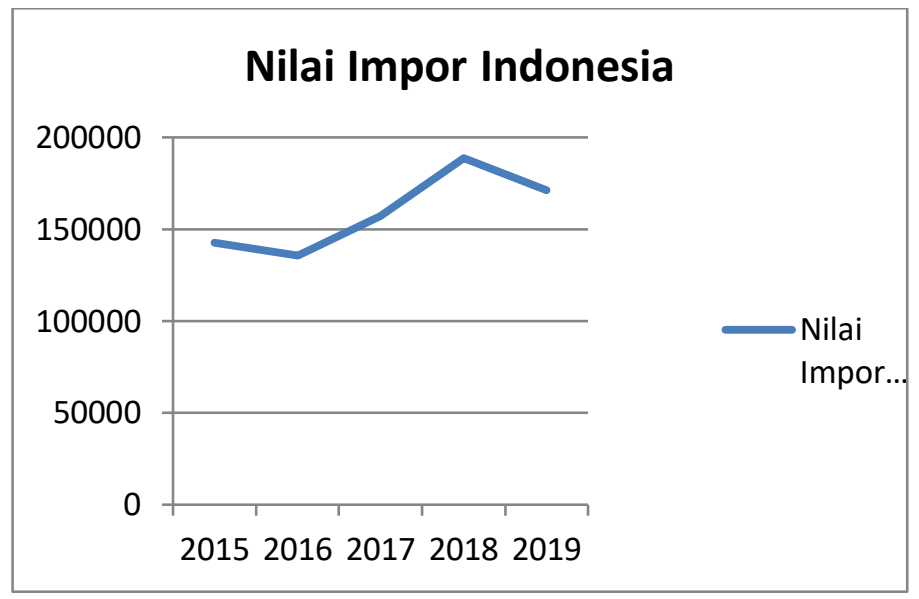

Sumber: Statistik Kementerian Perdagangan \& Badan Pusat Statistik (diolah kembali)

Pada tahun 2015 nilai impor Indonesia sebesar USD142.695 juta. Volume impor Indonesia mengalami penurunan pada tahun 2016 menjadi sebesar USD135.652 juta. Pada tahun 2017 dan 2018 nilai impor Indonesia terus mengalami kenaikan menjadi USD 156.986 juta dan USD188.711 juta. Nilai impor Indonesia tahun 2018 peningkatan sekitar 20,2 persen dari tahun 2017. Pada tahun 2019 nilai impor Indonesia tercatat sebesar USD 171.276 juta. Berdasarkan data tersebut dapat dilihat bahwa nilai impor Indonesia cenderung mengalami kenaikan. Meskipun nilai impor tahun 2016 mengalami penurunan dari tahun 2015, namun dari nilai impor tahun 2016 sampai dengan nilai impor tahun 2018 volume impor cenderung selalu mengalami peningkatan. Sampai pada tahun 2019, bahan baku atau penolong masih mendominasi persentase nilai impor Indonesia jika dilihat dari penggolongan kegunaan barang, yaitu sebesar 73,75 persen (BPS). Sedangkan 16,64 persen untuk barang modal dan 9,61 persen untuk barang konsumsi. Membandingkan persentase barang konsumi pada tahun 2018 sebesar 9,1 persen. Hal ini menunjukkan bahwa persentase impor barang konsumi mengalami kenaikan sebesar 5,6 persen.

Melihat nilai impor setiap tahunnya cenderung mengalami kenaikan Pemerintah mengeluarkan kebijakan menurunkan batas pembebasan nilai bea masuk barang kiriman melalui PMK No199/PMK.10/2019 tentang Ketentuan Kepabeanan, Cukai, dan Pajak atas Impor Barang Kiriman. Dalam Pasal 13 ayat (1) disebutkan: "barang kiriman yang diimpor untuk dipakai, diimpor sementara, diangkut ke TPS di kawasan Pabean, ditimbun di TPB, atau diekspor kembali dengan nilai FOB paling banyak sebesar USD3.00 per Penerima Barang dibebaskan dari Bea Masuk." Ambang batas pembebasan bea masuk impor barang kiriman mengalami penurunan dari USD75.00 menjadi USD3.00. Kebijakan penurunan ambang batas pembebasan bea masuk impor barang kiriman bertujuan untuk menciptakan keadilan dalam hal perpajakan, menciptakan tingkat persaingan yang adil demi melindungi industri lokal. Selain itu pemerintah juga menerima masukan dan saran dari industri lokal dari sektorsektor barang yang sering diimpor oleh masyarakat (DDTC, 2019). Ditambahnya dengan semakin mudahnya akses masyarakat melakukan impor melalui platform $e$-commerce yang menyediakan tempat untuk para produsen barang yang berasal dari luar negeri untuk memasarkan barang dagangannya 
kepada masyarakat lokal. Serta perkembangan e-commerce di Indonesia yang cukup pesat dan didominasi oleh produk impor (LIPI, 2019)

Kebijakan penurunan batas pembebasan nilai bea masuk barang kiriman ditetapkan beradasarkan statistik impor barang kiriman yang cenderung mengalami kenaikan mulai dari tahun 2017 sampai dengan 2019, yang dapat dilihat pada statistik berikut.

Grafik 2. Volume Impor Barang Kiriman Indonesia Tahun 2017-2019 (dalam US\$ Juta)

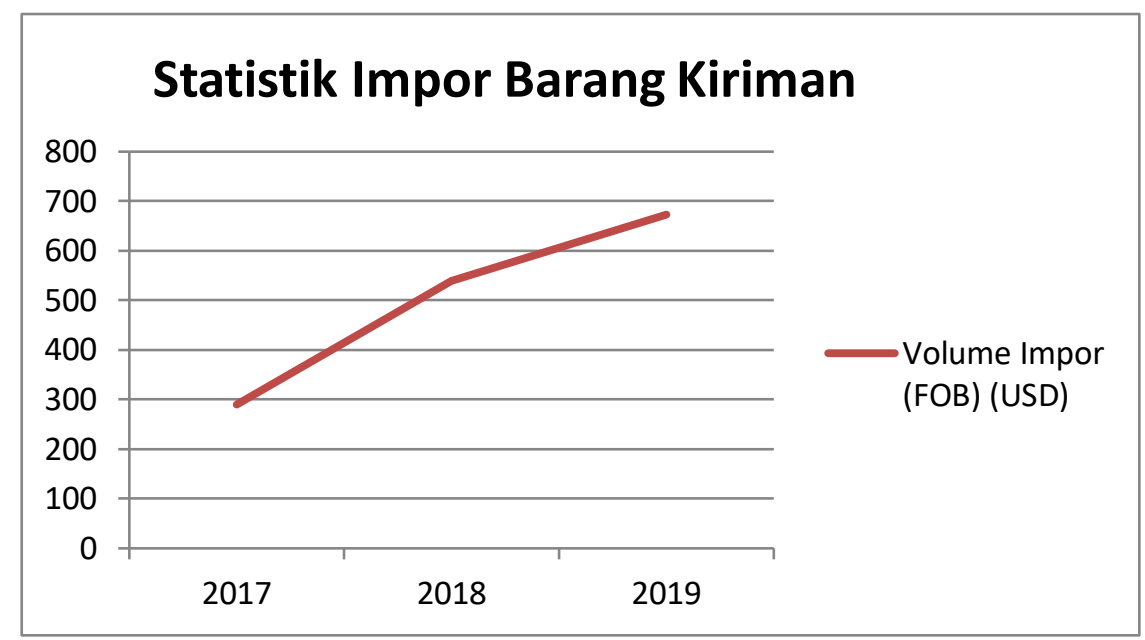

Sumber: Direktorat Jenderal Bea dan Cukai (diolah kembali)

Pada tahun 2017 volume impor barang kiriman sebesar USD290 Juta. Pada tahun 2018 volume impor barang kiriman menyentuh nominal USD540 Juta, menandakan volume impor barang kiriman mengalami kenaikan sebesar 86,2 persen dari jumlah volume tahun 2017. Pada tahun 2019 volume impor barang kiriman tercatat sebesar USD673 Juta, terjadi peningkatan sebesar 24,6 persen dari jumlah volume impor barang kiriman tahun 2018.

Sebelum mengeluarkan PMK No.199/PMK.10/2019 tentang Ketentuan Kepabeanan, Cukai, dan Pajak atas Impor Barang Kiriman, Pemerintah telah melakukan penurunan ambang batas nilai bea masuk nilai impor barang kiriman dari nilai USD100.00 menjadi USD75.00 sesuai dengan kebijakan PMK No.112/PMK.04/2018 tentang Perubahan PMK No.182/PMK/04/2016 Tentang Ketentuan Impor Barang Kiriman. Melihat data yang tersaji dalam Grafik 1.1, nilai impor Indonesia tahun 2019 mengalami penurunan sebesar 4,8 persen dari tahun 2018. Namun dalam Grafik 2 volume barang impor kiriman tidak menunjukkan terjadinya penurunan, justru terjadi peningkatan sebesar 24,6 persen.

Melihat dari kebijakan negara lain, nilai ambang batas yang ditetapkan Indonesia bahkan jauh lebih rendah dari nilai ambang batas yang ditetapkan oleh negara-negara di Asia yang juga menetapkan ambang batas pada nilai yang rendah. Seperti Thailand yang memiliki ambang batas USD49.00 dan China sebesar USD7.00. Namun tidak lebih rendah dari Ghana dan Liberia yang menetapkan ambang batas pembebasan bea masuk sebesar USD2.00. Serta Bangladesh, Paraguay, dan Costarica yang tidak memiliki ambang batas pembebasan bea masuk.

Berdasarkan latar belakang masalah yang telah dipaparkan, peneliti ingin mengetahui bagaimana pengaruh penurunan nilai ambang batas pembebasan bea masuk terhadap volume barang kiriman impor Indonesia?. Dengan tujuan (1) mengetahui bagaimana pengaruh penurunan nilai ambang batas pembebasan bea masuk terhadap volume barang kiriman impor Indonesia.

\section{KAJIAN PUSTAKA}

\section{Impor}

Impor merupakan kegiatan jual beli yang menyebabkan masuknya barang dari luar daerah pabean ke dalam daerah pabean (Tandjung, 2011). Menurut Purwito dan Indriani (2015) kegiatan impor diikuti dengan kewajiban pemenuhan kepabeanan yang dilakukan oleh importir (baik orang pribadi maupun 
badan). Dapat disimpulkan bahwa impor adalah kegiatan jual beli antar lintas negara yang wajib melewati serangkaian prosedur kepabeanan dan cukai untuk memasuki lintas batas suatu negara.

Konsep impor merupakan salah satu konsep yang terbentuk akibat perdagangan internasional. Krugman menjelaskan faktor-faktor yang menyebabkan terjadinya impor (dalam Imam, 2008) antara lain terjadinya keterbatasan sumber daya di suatu negara baik sumber daya manusia maupun teknologi, keterbatasan kuantitas suatu barang, dan terdapat barang yang tidak dapat diproduksi di suatu negara. Dapat disimpulkan bahwa kebutuhan impor akan muncul ketika tidak terpenuhinya suatu permintaan di dalam negeri.

Baigwell dan Staiger (2016) menyatakan bahwa impor dapat dihambat tidak hanya dengan melalui kebijaka penetapan tariff, namun juga penetapan kebijakan non-tariff seperti penetapan kuota impor, dan regulasi atau prosedur setiap negara (kepabeanan dan pajak dalam rangka impor) yang bermacam-macam sehingga dapat menimbulkan biaya lebih bagi importir. Hollow \& Rae (2012) menyatakan bahwa salah satu bentuk hambatan dalam perdagangan internasional dengan penetapan ambang batas deminimis value pada nilai yang rendah.

\section{Bea Masuk}

Menurut Purwito (2010) bea masuk adalah pungutan yang dikenakan oleh negara yang bersifat terutang akibat masuknya barang dari luar daerah pabean ke dalam daerah pabean. Definis lain menyebutkan bea masuk adalah pajak yang harus dibayar atas masuknya barang-barang impor (Krugman, 2003). Dalam literasi asing konsep bea masuk dikenal dengan istilah tariff.

Pengenaan bea masuk dalam lalu lintas perdagangan internasional sering digunakan sebagai alat proteksi untuk melindungi industri dalam negeri (Forum Studi Keuangan Negara, 2019). Dengan dikenakannya bea masuk terhadap barang impor akan menambah beban biaya yang akan menyebabkan harga jual barang menjadi lebih mahal. Tidak hanya sebagai alat proteksi, bea masuk juga disebut memiliki fungsi sebagai sumber penerimaan negara. J.Black menjabarkan terdapat tiga alasan negara menerapkan kebijakan bea masuk yang mana sebagai berikut:

\section{Mendistribusikan Pendapatan (Affect the Distribution of Incomes)}

J.Black (1959) menjelaskan bahwa kebijakan bea masuk merupakan salah satu motif pemerintah untuk mendapatkan pendapatan (revenue motive). Terjadi pendistribusian pendapatan dari masyarakat atau warga negara asing kepada pemerintah. Sebab bea masuk dikenakan terhadap barang impor dan bersifat pungutan, yang berarti wajib dibayar dengan mengalikan tarif tertentu yang ditetapkan oleh pemerintah. Akibat bea masuk bersifat pungutan maka wajib dibayarkan dan tidak melihat apakah dengan pengenaan bea masuk terhadap barang impor tersebut akan menimbulkan kerugian atau tidak bagi importir. Meskipun penerimaan pendapatan merupakan salah satu tujuan dari pengenaan bea masuk namun bukan untuk mendapatkan penerimaan pendapataan yang maksimal. Penerapan tarif maksimal hanya akan menambahkan beban biaya faktor produksi dan akan menekan keuntungan yang seharusnya diterima oleh importir.

2. Mempengaruhi Pemanfaatan Sumber Daya Negara atau Neraca Pembayaran (Affect the Degree of Utilization of a Country's Resources or Its Balance of Payments)

Kebijakan bea masuk dapat memberikan dampak terhadap keseimbangan tingkat perdagangan dan ketersediaan lapangan pekerjaan. Pemerintah perlu memastikan tarif yang akan ditetapkan cukup bagi pemerintah membelanjakan kembali hasil pungutan tersebut demi menjaga produktifitas ekonomi negara. Dengan kata lain, jangan sampai tarif bea masuk yang ditetapkan suatu negara menghambat produktifitas perekonomian negara. Penetapan tarif yang terlalu tinggi dapat menghambat produktifitas perdagangan negara.

3. Mempengaruhi Jumlah Produksi dan Konsumsi Negara (Affect the Composition of Production or Consumption)

Pengenaan bea masuk terhadap barang impor merupakan salah satu kebijakan yang bertujuan memberikan proteksi terhadap industri dalam negeri. Seperti pemerintah berusaha mengurangi ketergantungan terhadap produsen luar negeri terhdap produksi suatu barang. Pengenaan bea masuk akan menciptakan playing field yang adil bagi produsen luar negeri maupun dalam negeri dalam bersaing menjual produknya. Apalagi pada kasus barang yang secara keseluruhan memiliki faktorfaktor produksi yang serupa. Konsumen cenderung akan memilih membeli barang yang memiliki 
harga lebih rendah dalam kondisi kualitas yang serupa. Kebijakan pengenaan bea masuk akan membantu hasil produksi dalam negeri bersaing dengan hasil produksi luar negeri.

\section{Ambang Batas Pembebasan Bea Masuk (De Minimis Value Threshold)}

Menurut OECD, batasan pembebasan bea masuk (de minimis) merupakan istilah yang digunakan saat kebijakan perpajakan tidak diterapkan dalam memungut pajak terutang akibat nilai pajak yang terutang tidak melebihi batas nimai minimal. Ambang batas pembebasan bea masuk mengacu pada nilai barang impor tidak mencapai batas nilai pengenaan bea masuk sehingga tidak dikenakan pajak dan bea cukai (Hufbauer, Lu \& Jung, 2018). Batasan pembebasan bea masuk adalah nilai pabean tertentu yang ditetapkan sebagai batasan untuk mendapatkan fasilitas pembebasan bea masuk yang ditetapkan dalam peraturan perundang-undangan.

Kebijakan ambang batas pembebasan bea masuk dapat dikatakan sebagai salah satu bentuk fasilitas dalam perdagangan internasional. Penetapan ambang batas pembebasan bea masuk merupakan salah satu cara yang dapat dilakukan oleh pemerintah untuk mengefisiensikan prosedur perdagangan internasional dalam bentuk regulasi yang sah (Latipov, 2017).

Nilai ambang batas pembebasan bea masuk yang tinggi tidak hanya memperlancar arus perdagangan internasional, namun juga dapat mengurangi compliance cost yang harus ditanggung oleh importir (Holloway \& Rae, 2012). Sebaliknya, Holloway \& Rae juga menyebutkan, apabila nilai ambang batas pembebasan bea masuk ditetapkan pada nilai yang rendah merupakan salah satu faktor penghambat dalam perdagangan internasional. Selain meningkatkan compliance cost, adanya kemungkinan importir melakukan penghindaran pajak juga semakin tinggi, dan timbulnya time cost yang disebabkan oleh estimasi sampainya barang lebih lama akibat harus melewati serangkaian prosedur kepabeanan negara. Timbulnya time cost ini dapat mempengaruhi minat beli konsumen terhadap suatu barang.

Ketentuan mengenai nilai ambang batas pembebasan bea masuk di Indonesia diatur lebih rinci dalam Pasal 13 ayat (1) PMK No199/PMK.10/2019 tentang Ketentuan Kepabeanan, Cukai, dan Pajak atas Impor Barang Kiriman. Disebutkan bahwa nilai impor barang kiriman sampai dengan FOB USD3.00 per Penerima Barang per kiriman akan dibebaskan dari bea masuk, Pajak Pertamabahan Nilai (PPN) dan Pajak Penjualan atas Barang Mewah (PPnBM), dan dikecualikan dari pemungutan Pajak Penghasilan (PPh).

\section{METODOLOGI}

Pendekatan yang digunakan dalam penelitian ini adalah pendekatan kualitatif. Menurut Boghdan \& Biklen (1975) pendekatan kualitatif adalah salah satu jenis model penelitian yang mengandalkan sikap objek yang diamati untuk menghasilkan suatu penjelasan deskriptif. Dalam penelitian ini penulis bertujuan untuk menjelaskan pengaruh kebijakan penurunan nilai ambang batas pembebasan bea masuk terhadap volume impor barang kiriman dengan menggunakan data-data sekunder yang berhubungan dengan penelitian. Dalam melakukan analisis, penulis menggunakan data volume impor barang kiriman dan jumlah consignment notes bulan Januari-Juli tahun 2019 dan 2020 yang bersumber dari Direktorat Jenderal Bea Cukai. Data sekunder lainnya didapatkan dari buku, jurnal ilmiah, dan penelitian-penelitian sejenis yang dapat menudukung analisis penulis. Data didapatkan dengan menggunakan metode studi kepustakaan dimana penulis melakukan pengumpulan data dengan mempelajari buku, jurnal, dan sumber-sumber ilmiah terkait yang berhubungan dengan pengaruh penurunan nilai ambang batas pembebasan bea masuk (Zed, M. 2004)

\section{HASIL DAN PEMBAHASAN}

\section{Prosedur Kepabeanan Impor Barang Kiriman}

Merujuk pada ketentuan PMK No199/PMK.10/2019 tentang Kepabeanan, Cukai, dan Pajak atas Impor Barang Kiriman. Pada pasal 2 ayat (1) kewajiban kepabeanan yang wajib dilaksanakan yaitu pembayaran bea masuk, cukai, dan/atau pajak dalam rangka impor atas barang kiriman dilakukan oleh penyelenggara pos. Barang kiriman akan dilakukan pemeriksaan secara fisik, yang meliputi pemeriksaan fisik dan dokumen (consignment notes) oleh Petugas Pos atau Petugas PJT. Consignment 
notes atau disebut dengan dokumen barang merupakan dokumen pengiriman barang antar penyelenggara pengiriman barang dengan penerima barang. Penyelanggara pos akan memberikan consignment notes yang berisikan detail mengenai barang kiriman, yang kemudian akan dihitung kewajiban kepabeanan oleh Pejabat Bea Cukai dan harus dibayar oleh Importir melalui penyelenggara pos agar dapat dikeluarkan dari Tepat Penimbunan Sementara (TPS). Apabila nilai barang kiriman melewati ambang batas pembebasan bea masuk, akan dikenalan bea masuk sebesar 7,5\%, Pajak Pertambahan Nilai (PPN) sebesar 10\%, dan PPh sebesar 10\% (apabila memiliki NPWP) atau 20\% (apabila tidak memiliki NPWP). Apabila barang kiriman tersebut merupakan objek cukai, maka akan dikenakan cukai sesuai dengan tarif yang diatur dalam peraturan perundang-undangan. Barang kiriman baru akan dikirimkan kepada Importir melalui penyelenggara pos setelah seluruh kewajiban kepabeanan dilaksanakan.

\section{Data Volume Impor Barang Kiriman Bulan Januari - Juli 2020}

Semenjak kebijakan penurunan ambang batas pembebasan bea masuk nilai impor barang kiriman yang tertuang dalam PMK No 199/PMK.10/2019 berlaku secara efektif. Berikut grafik volume impor barang kiriman Indonesia bulan Januari sampai dengan Juli 2020:

Grafik 3. Volume Impor Barang Kiriman Indonesia Januari - Juli 2020 (dalam US\$ Juta)

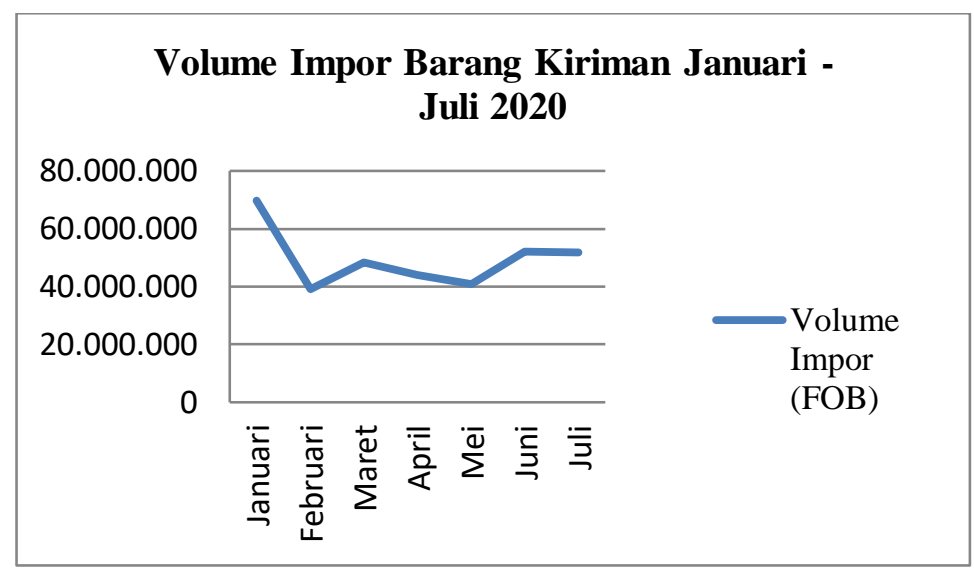

Sumber: Direktorat Jenderal Bea \& Cukai (diolah kembali)

Melihat pada grafik statistik, Januari 2020 nilai volume impor barang kiriman tercatat sebesar USD69,72 juta. Pada Februari mengalami penurunan sebesar 44persen menjadi USD39,1 juta. Pada Maret 2020 tercatat sebesar USD48,27 juta, terjadi kenaikan sebesar 23 persen dibandingkan dengan bulan Februari. Pada bulan April dan Mei cenderung mengalami penurunan menjadi USD43,9 Juta dan USD40,9 Juta. Terjadi penurunan masing-masing sebesar 9 persen dan 7 persen. Pada bulan Juni tercatat sebesar USD51,9 Juta dan bulan Juli sebesar USD51,7 Juta. Pada bulan Februari 2020 terjadi penurunan yang cukup signifikan, persentase penurunan menyentuh angka 44 persen. Namun nilai volume impor barang pada bulan Maret sampai dengan Mei tidak mengalami perubahan yang begitu signifikan. Pada bulan Juni nilai volume impor barang kiriman kembali mengalami peningkatan sebesar 26 persen jika dibandingkan dengan bulan Mei. 
Perbandingan Data Volume Impor Barang Kiriman Bulan Januari - Juli Tahun 2019 \& 2020

Tabel 1. Perbandingan Volume Impor Barang Kiriman Indonesia Januari-Juli 2019 \& 2020 (dalam US\$ Ribu)

\begin{tabular}{|l|r|r|r|}
\hline \multicolumn{1}{|c|}{ Bulan } & $\mathbf{2 0 1 9}$ & \multicolumn{1}{c|}{$\mathbf{2 0 2 0}$} & \multicolumn{1}{c|}{$\begin{array}{c}\text { Perubahan } \\
\text { (persen) }\end{array}$} \\
\hline Januari & 51.217 .770 & 69.723 .017 & $36 \%$ \\
\hline Februari & 41.042 .814 & 39.105 .473 & $-5 \%$ \\
\hline Maret & 56.931 .406 & 48.274 .476 & $-15 \%$ \\
\hline April & 57.360 .231 & 43.972 .910 & $-23 \%$ \\
\hline Mei & 63.690 .578 & 40.982 .863 & $-36 \%$ \\
\hline Juni & 53.726 .942 & 51.960 .414 & $-3 \%$ \\
\hline Juli & 75.204 .827 & 51.726 .734 & $-31 \%$ \\
\hline Total & 399.174 .568 & 345.745 .887 & $-13 \%$ \\
\hline
\end{tabular}

Sumber: Direktorat Jenderal Bea \& Cukai (diolah kembali)

Jika melihat tabel perbandingan volume barang kiriman impor sepanjang bulan Januari sampai dengan Juli pada tahun 2019 dan 2020, kebijakan penurunan nilai ambang batas pembebasan bea masuk menekan angka volume impor barang kiriman. Penurunan tertinggi terjadi pada perbandingan bulan Mei yang mencapai 36 persen, sedangkan penurunan terendah terjadi pada bulan 3 persen. Secara keseluruhan volume impor barang kiriman Januari-Juli 2020 mengalami penurunan sebesar 13 persen dari jumlah volume impor barang kiriman Januari-Juli 2019.

\section{Perbandingan Jumlah Consignment Note Barang Kiriman Bulan Januari - Juli Tahun 2019 \& 2020}

Penurunan volume impor barang kiriman Januari - Juli 2020 diikuti dengan penurunan jumlah consignment notes yang dicatat oleh Direkrotat Jenderal Bea Cukai. Jika membandingkan data yang tercatat pada Januari-Juli 2019 dan Januari-Juli 2020, adapun perbandingannya dapat dilihat sebagai berikut.

Tabel 2. Perbandingan Perbandingan Jumlah Consignment Note Barang Kiriman Bulan Januari - Juli Tahun 2019 \& 2020

\begin{tabular}{|l|r|r|r|}
\hline \multicolumn{1}{|c|}{ Bulan } & \multicolumn{1}{c|}{2019} & \multicolumn{1}{c|}{$\begin{array}{c}\text { Perubahan } \\
\text { (persen) }\end{array}$} \\
\hline Januari & 2.589 .047 & 4.519 .386 & $75 \%$ \\
\hline Februari & 2.150 .303 & 2.194 .057 & $2 \%$ \\
\hline Maret & 2.955 .821 & 2.591 .360 & $-12 \%$ \\
\hline April & 3.549 .745 & 3.004 .230 & $-15 \%$ \\
\hline Mei & 4.697 .374 & 3.802 .159 & $-19 \%$ \\
\hline Juni & 3.909 .399 & 4.097 .381 & $5 \%$ \\
\hline Juli & 5.753 .771 & 3.765 .226 & $-35 \%$ \\
\hline Total & 25.605 .460 & 23.973 .799 & $-6 \%$ \\
\hline
\end{tabular}

Sumber: Direktorat Jenderal Bea \& Cukai (diolah kembali)

Melihat tabel perbandingan jumlah consignment note barang kiriman bulan Januari - Juli Tahun 2019 \& 2020. Pada perbandingan pada bulan Januari terjadi peningkatan yang cukup signifikan yaitu sebesar 75 persen. Bulan berikutnya, Februari mengalami peningkatan sebesar 2persen namun jika membandingkan dengan persentase perubahan bulan Januari, terjadi penurunan yang cukup signifikan hingga 73 persen. Pada bulan-bulan berikutnya perbandingan jumlah bulan-bulan berikutnya cenderung mengalami penurunan. Dengan penurunan tertinggi terjadi pada perbandingan bulan Juli yaitu sebesar 35 persen. Secara keseluruhan jumlah consignment notes impor barang kiriman Januari-Juli 2020 mengalami penurunan sebesar 6 persen dari jumlah consignment notes barang kiriman Januari-Juli 2019. 


\section{Faktor - Faktor Penurunan Volume Impor Barang Kiriman Januari-Juli 2020}

1. Kebijakan Pembatasan Sosial Secara Berkala (PSBB) akibat Pandemi COVID 19

Selain akibat kebijakan penurunan ambang batas nilai penyebab terjadinya penurunan volume impor barang kiriman yang secara signifikan juga diakibatkan oleh faktor-faktor berikut. Pertama, adanya pembatasan penerbangan yang dikeluarkan oleh Pemerintah sebagai upaya pencegahan penyebaran virus COVID-19. Merujuk pada Peraturan Menteri Kesehatan Republik Indonesia Nomor 9 Tahun 2020 tentang Pedoman Pembatasan Sosial Berskala Besar dalam Rangka Percepatan Penanganan Corona Virus Diseases 2019, perusahaan logistik yang termasuk perusahaan pelayaran, penyebrangan dan penerbangan untuk angkutan barang tetap beroperasi namun dengan jumlah pembatasan karyawan dan harus memperhatikan protocol kesehatan. Sebagai akibatnya jumlah penerbangan atau keberangkatan moda transportasi pengangkut barang kiriman turut dibatasi, mengutip pernyataan dari Zaldy Ilham Masita, Ketua Umum Asosiasi Logistik Indonesia (Tempo, 2020). Sehingga estimasi waktu sampai memakan waktu lebih lama dari estimasi normal. Seiring dengan kebijakan New Normal yang diterapkan pada 1 Juni 2020 oleh pemerintah, grafik volume impor barang kiriman Juli 2020 kembali mengalami kenaikan dan nominalnya hampir menyamai nominal volume impor barang kiriman Juli 2019. Selain dari moda jasa pengiriman barang, waktu proses prosedur pemeriksaan bea dan cukai memakan waktu lebih lama akibat aturan pembatasan sosial yang ditetapkan oleh pemerintah untuk membatasi kuantitas tenaga kerja dan mengurangi waktu kerja.

2. Menurunnya Laju Perdagangan Negara Eksportir

Menurut data Badan Pusat Statistik (BPS), negara yang paling banyak menyumbang angka impor di Indonesia ialah Amerika Serikat, Tiongkok (Cina), dan Thailand. Tercatat nilai impor non migas dari Tingkok (Cina) USD44.5 juta, menyumbang nilai impor Indonesia sebanyak 29,95persen dari total keseluruhan. Semenjak virus Corona merebak, terutama Cina, lebih fokus menekan angka penyebaran virus Corona sehingga timbulnya kebijakan seperti lock down atau pembatasan sosial yang mengharuskan masyarakat melakukan isolasi diri di rumah sehingga mengurangi aktifitasnya selama periode waktu yang ditentukan. Kebijakan tersebut berdampak terhadap laju perdagangan negara. Cina akibat wilayah Wuhan, yang merupakan kawasan industri, diberlakukan kebijakan lockdown oleh pemerintah Cina untuk mengurangi penyebaran virus. Kinerja ekspor negara Cina tercatat mengalami penurunan hinga 17,2 persen (CNN, 2020). Nilai Impor non migas dari Cina pada Januari 2020 tercatat sebesar USD 3,9 Juta, nilai ini mengalami penurunan sebesar 3 persen dari nilai impor Desember 2019 yang tercatat sebesar USD 4 juta. Tidak hanya di Cina penurunan nilai impor dari negara penyumbang terbesar lain, yaitu Amerika Serikat dan Thailand juga mengalami penurunan sebesar 14 persen dan 4,8 persen.

3. Penurunan Daya Beli Masyarakat

Penurunan daya beli masyarakat Indonesia akibat pandemi COVID 19 yang mengakibatkan terbatasnya aktivitas masyarakat. Menurut BPS, pertumbuhan konsumsi rumah tangga tiga bulan pertama (Januari, Februari, dan Maret) pada tahun 2020 tercatat sebesar 2,84 persen (Tempo, 2020). Angka tersebut lebih kecil jika dibandingkan dengan angka pertumbuhan tahun lalu yang sebesar 5 persen. Penurunan daya beli masyarakat akan berdampak pada penurunan nilai impor Indonesia karena sebagain besar penyumbang nilai impor merupakan barang rumah tangga.

\section{Penentuan Nilai Ambang Batas Pembebasan Bea Masuk (Deminimis Threshold)}

Dalam menetapkan nilai ambang batas pembebasan bea masuk impor barang kiriman, pemerintah perlu mempertimbangkan konsekuensi yang dapat ditimbulkan. Merujuk pada penelitian yang dilakukan oleh Latipov, Mcdaniel, dan Schropp (2017) yang membandingkan dampak yang terjadi apabila peneapan nilai ambang batas dalam nilai yang cukup tinggi dan rendah dengan melihat negara Amerika Serikat dan Cina. Apabila pemerintah memiliki tujuan untuk memperlancar arus perdagangan internasional, nilai ambang batas pembebasan bea masuk lebih baik ditetapkan pada nominal yang cukup tinggi. Impor tidak selalu bermakna buruk bagi neraca perdagangan suatu negara, impor juga dapat mendorong pertumbuhan perdagangan nasional (Wulandari \& Lubis, 2019). Tidak hanya memperlancar arus perdagangan internasional, biaya produksi barang bagi industri yang salah satu bahan bakunya 
harus diimpor akan semakin rendah sehingga dapat menekan harga jual serta mengefisiensikan waktu produksi barang.

Jika pemerintah berorientasi pada peningkatan pendapatan negara, nilai ambang batas pembebasan bea masuk memang lebih baik ditetapkan pada nilai yang cukup rendah. Selain berimbas pada penurunan volume impor barang kiriman Indoensia, terjadi peningkatan penerimaan pada sektor bea masuk, pajak dalam rangka impor, dan PPN \& PPnBM. Berdasarkan data dari Direktorat Jenderal Bea Cukai, penerimaan yang bersumber dari bea masuk pada periode Januari-Juli 2019 tercatat sebesar Rp475,35 Milyar, sedangkan pada periode Januari-Juli 2020 tercatat sebesar Rp1,17 Trilyun. Dengan membandingkan dua data tersebut dapat dilihat bahwa terjadi peningkatan yang cukup signifikasn hingga mencapai 146persen. Dengan diturunkannya nilai ambang batas bea masuk impor barang kiriman, akan semakin banyak transaksi impor barang kiriman yang terkena bea masuk. Pernyataan ini disimpulkan dari data Direktorat Jenderal Bea Cukai yang mencatat nilai rata-rata impor barang kiriman yang memiliki nilai lebih dari USD75 pada tahun 2019 memiliki persentase sebesar 98,71persen. Sesuai dengan teori yang dikemukakan oleh J.Black mengenai tujuan pemerintah mengeluarkan kebijakan pengenaan bea masuk terhadap barang impor. Kebijakan penurunan nilai ambang batas pembebasan bea masuk mempengaruhi Affect the Distribution of Incomes.

Sebab nilai ambang batas pembebasan bea masuk pada nilai yang rendah akan memperkecil kuantitas barang impor kiriman yang mendapat fasilitas pembebasan bea masuk, serta menambah biaya yang harus dikeluarkan oleh konsumen untuk membeli barang dengan cara impor. Sehingga akan menimbulkan kecenderungan perilaku konsumen yang mengurungkan niat untuk membeli atau memilih membeli produk sejenis dengan kualitas dan serupa yang dihasilkan oleh produsen lokal. Menimbang waktu dalam mendapatkan barang yang dibutuhkan lebih efisien ketimbang mengimpor barang tersebut. Kebijakan penetapan pembebasan bea masuk pada nilai yang rendah cenderung cocok untuk negara yang nilai impornya tinggi apalagi pelaku bisnis didominasi oleh retailers (Latipov, Mcdaniel, dan Schropp, 2017).

Kebijakan penurunan nilai ambang batas pembebasan bea masuk impor sebenarnya baru akan benar-benar berpengaruh terhadap volume impor barang jika berdampak pada barang yang bersifat elastis. Artinya permintaan terhadap suatu barang baru akan begitu terdampak ketika terjadi perubahan harga (Rudi \& Suparta, 2016). Apabila barang tidak bersifat elastis, dalam artinya barang tersebut permintaan suatu barang tidak akan terpengaruh jika terjadi perubahan harga, maka kebijakan penurunan ambang batas pembebasan bea masuk impor barang kiriman tidak akan menurunkan volume impor barang kiriman.

\section{KESIMPULAN}

Setelah ditetapkannya kebijakan penurunan ambang batas pembebasan bea masuk impor barang kiriman menunjukkan bahwa terjadinya penurunan volume impor barang kiriman. Membandingkan volume impor barang kiriman Januari-Juli 2019 dengan Januari-Juli 2020 menunjukkan terjadinya penurunan sebesar 10,24 persen. Serta total rata-rata perbandingan data tahun 2019 dan 2020 menunjukkan terjadinya penurunan sebesar 13 persen seperti yang ditunjukkan pada tabel 1 . Data tersebut menunjukkan bahwa kebijakan penurunan nilai ambang batas pembebasan bea masuk impor barang kiriman mampu membantu menekan nilai volume impor barang kiriman. Selain dari sisi kebijakan, penurunan volume impor barang kiriman pada saat ini terjadi disebabkan oleh kondisi pandemi COVID 19 yang nyatanya turut menghambat laju perdagangan baik dari dalam negeri maupun luar negeri sehingga volume impor barang kiriman periode Februari-Juli 2020 cenderung mengalami penurunan. Kondisi ini berimbas pada terjadinya pembatasan jadwal penerbangan selama beberapa waktu, menurunnya aktivitas perdagangan akibat pembatasan gerak yang ditetapkan oleh pemerintah kepada masyarakat sehingga terjadinya penurunan daya beli masyarakat. Selain berdampak pada penurunan volume impor barang kiriman, kebijakan penurunan nilai ambang batas impor barang kiriman berdampak terhadap peningkatan pendapatan negara dari sektor bea masuk pada Januari-Juli 2020 mengalami peningkatan sebesar 146 persen dari penerimaan sektor bea masuk periode Januari-Juli 2019. 


\section{Saran}

Kebijakan penurunan ambang batas pembebasan bea masuk impor barang kiriman (PMK No 199/PMK.10/2019) masih perlu ditinjau kembali meskipun grafik statistik data volume impor barang kiriman Januari-Juli 2020 cenderung menunjukkan penurunan dan setelah dibuat perbandingan dengan data Januari-Juli 2019 terjadi perbedaan yang cukup signifikan. Namun, ketika pemerintah menetapkan kebijakan New Normal yang sedikit melonggarkan ruang gerak masyarakat dalam beraktivitas pada bulan Juli. Grafik 3. menunjukkan terjadinya pergerakan peningkatan kembali. Bahkan nilai volume impor barang kiriman Juli 2020 hampir menyamai nilai volume impor barang kiriman Juli 2019. Dimana nilai ambang batas pembebasan bea masuk masih berada pada nilai USD75. Mengingat sebelumnya pemerintah telah mencoba volume impor barang kiriman dengan menurunkan nilai ambang batas pembebasan bea masuk dari USD100 menjadi USD75. Justru, volume impor barang kiriman cenderung mengalami kenaikan seperti yang ditunjukkan pada Grafik 1.2 pada saat kondisi ruang gerak aktivitas masyarakat, termasuk perdagangan, telah diberi kelonggaran. Hal ini menunjukkan adanya kemungkinan kebijakan penurunan nilai ambang batas pembebasan bea masuk tidak begitu berpengaruh terhadap penuruan volume impor barang kiriman.

Apabila kondisi laju perdagangan dan perekonomian sudah berangsur membaik dan normal, pemerintah dapat meninjau dan melihat sektor komoditi yang cenderung diimpor oleh masyarakat dan menyelaraskan dengan perkembangan industri lokal agar kebijakan kepabeanan cukai dapat memberikan dampak yang efektif dan efisien bagi pertumbuhan ekonomi nasional. Salah satu tujuan ditetapkannya kebijakan penurunan nilai ambang batas pembebasan bea masuk impor barang kiriman adalah untuk menciptakan kesetaraan persaingan antar produsen luar negeri dengan produsen dalam negeri. Jangan sampai ketika nilai ambang batas pembebasan bea masuk sudah rendah, namun ternyata produsen dalam negeri perlu melakukan impor untuk memenuhi kebutuhan proses produksi. Serta melakukan pengawasan yang lebih ketat agar modus penghindaran pajak dapat diminimalisir dalam rangka mengamankan penerimaan negara.

\section{TINJAUAN PUSTAKA}

\section{Buku}

Ali, P. Indriani.(2015). Ekspor, Impor, Sistem Harmonisasi, Nilai Pabean dan Pajak dalam Kepabeanan. Tandjung, M. (2011). Aspek dan prosedur ekspor-impor. Jakarta: Salemba Empat.

Zed, M. (2004). Metode peneletian kepustakaan. Yayasan Obor Indonesia.

\section{Jurnal}

Black, J. (1959). Arguments for Tariffs. Oxford Economic Papers, 11(2), new series, 191-208. Retrieved August 27th, 2020, from http://www.jstor.org/stable/2662123

Bagwell, K., \& Staiger, R. W. (2016). Handbook of Commercial Policy. Elsevier, 213-214.

El-Osta, B., MacPhee, C. R., \& Rosenbaum, D. I. (1996). International trade, foreign direct investment, and domestic market performance. Eastern Economic Journal, 22(1), 63-74.

Holloway, S., \& Rae, J. (2012). De minimis thresholds in APEC. World Customs Journal, 6(1), 31-62.

Hufbauer, G. C., Lu, Z. L., \& Jung, E. (2018). The Case for Raising de minimis Thresholds in NAFTA 2.0 (No. PB18-8).

Imam, A. (2013). Faktor-Faktor Yang Mempengaruhi Impor Barang Konsumsi Di Indonesia. Jurnal Kajian Ekonomi dan Pembangunan, 1(02).

Latipov, O., McDaniel, C., \& Schropp, S. (2018). The de minimis threshold in international trade: The costs of being too low. The World Economy, 41(1), 337-356.

Oke, A. O., Kamolshotiros, P., Popoola, O. Y., Ajagbe, A. M., \& Olujobi, J. O. (2016). Consumer behavior towards decision making and loyalty to particular brands. International Review of Management and Marketing, 6, 43-52. 
Obstfeld, M., \& Krugman, P. R. (2003). International Economics: Theory and Policy. Pearson Education, Inc.

Rusdi, M. D., \& Suparta, M. (2016). Analisa Faktor-faktor yang Mempengaruhi Permintaan Daging Sapi di Kota Surabaya. JEB17: Jurnal Ekonomi dan Bisnis, 1(02).

Wulandari, S., \& Lubis, A. S. Analisis Perkembangan Ekspor Impor Barang Ekonomi di Provinsi Sumatera Utara. Jurnal Administrasi Bisnis, 8(1), 31-36.

\section{Portal Berita}

Ekspor China Anjlok Imbas Virus Corona. https://www.cnnindonesia.com/ekonomi/20200113181248-532-464991/ekspor-china-anjlokimbas-virus-corona. Diakses pada 6 September 2020, pukul 18:16

Pengiriman Barang Terganjal Pembatasan Penerbangan, Tempo. https://koran.tempo.co/read/ekonomidan-bisnis/451912/pengiriman-barang-terganjal-pembatasan-penerbangan. Diakses pada 9 September 2020, pukul 19:08.

Ambang Batas Pembebasan Bea Masuk Diturunkan Lagi, Ada Apa?. https://news.ddtc.co.id/ambangbatas-pembebasan-bea-masuk-diturunkan-lagi-ada-apa-18192?page $\mathrm{y}=1155$. Diakses pada 7 Oktober 2020, pukul 20:47.

\section{Publikasi Online}

Forum Studi Keuangan Negara. (2019). Esai Keuangan Negara: Kebijakan APBN dalam Meningkatkan Kesejahteraan Masyarakat.

Glossarium OECD. https://www.oecd.org/ctp/glossaryoftaxterms.htm. Diakses pada 27 Agustusts 2020 pukul 15:14.

Rekomendasi LIPI untuk Kebijakan E-Commerce Indonesia. (2019). LIPI. http://lipi.go.id/siaranpress/rekomendasi-lipi-untuk-kebijakan-e-commerce-indonesia/21898. Diakses pada 1 September 2020 pukul 17:19.

Statistik, B. P. (2019). Perkembangan Ekspor dan Impor Indonesia Desember 2019. Tersedia pada: https://www. bps. go. id.

\section{Regulasi}

PMK No199/PMK.10/2019 tentang Ketentuan Kepabeanan, Cukai, dan Pajak atas Impor Barang Kiriman

PMK No.112/PMK.04/2018 tentang Perubahan PMK No.182/PMK/04/2016 Tentang Ketentuan Impor Barang Kiriman

Undang-Undang Nomor 17 Tahun 2006 tentang Perubahan atas Undang-Undang Nomor 10 Tahun 1995 tentang Kepabeanan

\section{Statistik}

Statistik Nilai Impor Indonesia Tahun 2015-2019. Badan Pusat Statistik.

Statistik Nilai Impor Indonesia Tahun 2015-2019. Statistik Kementerian Perdagangan.

Statistik Jumlah Consignment Notes Bulan Januari-Juli 2019 \& 2020. Direktorat Jenderal Bea Cukai

Statistik Volume Barang Kiriman Impor Indonesia Tahun 2017-2019. Direktorat Jenderal Bea Cukai

Statistik Volume Barang Kiriman Impor Indonesia Tahun 2019. Direktorat Jenderal Bea Cukai.

Statistik Volume Barang Kiriman Impor Indonesia Januari-Juli 2020. Direktorat Jenderal Bea Cukai 